\title{
Resistance to barley yellow dwarf luteovirus in Aegilops species
}

\author{
K. M. Makkouk ${ }^{1}$, A. Comeau ${ }^{2}$, and W. Ghulam ${ }^{1}$ \\ ${ }^{1}$ Virology Laboratory, Genetic Resources Unit, International Center for Agricultural Research in the Dry \\ Areas (ICARDA), P.O. Box 5466, Aleppo, Syria; and ${ }^{2}$ Agriculture Canada, Station de Recherches, 2560 \\ Hochelaga BIVd., Sainte-Foy, Quebec, Canada G1V 2J3. Received 22 July 1993, accepted 7 January 1994.
}

\begin{abstract}
Makkouk, K. M., Comeau, A. and Ghulam, W. 1994. Resistance to barley yellow dwarf luteovirus in Aegilops species. Can. J. Plant Sci. 74: 631-634. One thousand and ninety-seven Aegilops accessions were evaluated for their reaction to a PAV serotype of barley yellow dwarf luteovirus (BYDV). The accessions tested belong to the species bicornis, biuncialis, caudata, crassa, columnaris, comosa, cylindrica, kotschyi, longissima, mutica, neglecta (= triaristata $4 \times$ ), ovata, peregrina, searsii, sharonensis, speltoides, tauschii (= squarrosa), triuncialis, umbellulata, uniaristata, vavilovii and ventricosa. The first evaluation of virus levels in the different accessions was conducted at International Center for Agricultural Research in the Dry Areas (ICARDA), Aleppo, Syria, using double antibody sandwich ELISA (DAS-ELISA). Accession reaction ranged from highly resistant to highly susceptible. Thirty-eight Aegilops accessions resistant at ICARDA, were evaluated at Sainte-Foy, Quebec, Canada, by tissue-blot immunoassay. Diversity of response to BYDV infection was again observed in this elite group. Seven accessions belonging to the species biuncialis, caudata, neglecta and triuncialis were highly BYDV resistant at both locations; five of these originated from Bulgaria.
\end{abstract}

Key words: Introgression, interspecific, Triticum aestivum, BYDV, ELISA, immunoassay, tissue blot

Makkouk, K. M., Comeau, A. et Ghulam, W. 1994. Résistance au virus de la jaunisse nanisante de l'orge chez les espèces d'Aegilops. Can. J. Plant Sci. 74: 631-634. Mille quatre vingt dix sept lignées d'Aegilops furent évaluées pour leur réaction au sérotype PAV de la jaunisse nanisante de l'orge (VJNO). Ces lignées appartenaient aux espèces bicomis, biuncialis, caudata, crassa, columnaris, comosa, cylindrica, kotschyi, longissima, mutica, neglecta (= triaristata $4 \times$ ), ovata, peregrina, searsii, sharonensis, speltoides, tauschii ( = squarrosa), triuncialis, umbellulata, uniaristata, vavilovii et ventricosa. La première évaluation des diverses lignées fut faite à ICARDA, Alep, Syrie, par le "double antibody sandwich ELISA" DAS-ELISA. Les réactions furent très diverses, entre la forte résistance et la forte sensibilité. Trente-huit lignées d'Aegilops classées résistantes à ICARDA furent réévalués à Ste-Foy, Canada par un essai sérologique sur l'empreinte de tissu. Une certaine diversité de réponse à l'infection virale fut encore observée parmi ces sélections. Sept lignées, appartenant aux espèces biuncialis, caudata, neglecta et triuncialis, furent très résistantes au VJNO aux deux sites d'essai, et cinq de ces lignées étaient originaires de Bulgarie.

Mots clés: Introgression, interspécifique, Triticum aestivum, VJNO, ELISA, essai sérologique, empreinte de tissu

Barley yellow dwarf luteovirus (BYDV) is an important disease of cereals, and the search for resistance to this virus in wild relatives is economically justified. Several researchers (Sharma et al. 1984; Brettell et al. 1988; Ceoloni et al. 1988) have reported desirable traits in the wild relatives of cereals. Those traits constitute an important genetic resource for cereal improvement (Cauderon 1979). Aegilops species are often used in interspecific hybridization with durum (Triticum durum) and bread wheat (Triticum aestivum). The $\mathrm{F}_{1}$ hybrids can be rescued and backcrossed with relative ease (Comeau and St-Pierre 1992; Comeau et al. 1993). There are no previous reports of BYDV resistance in this genus.

The Gene Bank of the International Center for Agricultural Research in the Dry Areas (ICARDA) has a large collection of Aegilops species. In this study we evaluated 1097 Aegilops accessions for their reaction to BYDV.

\section{MATERIALS AND METHODS}

\section{Germplasm Evaluated}

During the 1988-1992 growing seasons the following Aegilops accessions were evaluated at ICARDA in Syria:
10 Ae. bicornis, 123 Ae. biuncialis (syn. macrochaeta), 15 Ae caudata (syn. dichasians), 16 Ae. columnaris, 3 Ae. comosa, 7 Ae crassa, 60 Ae. cylindrica, 30 Ae. kotschyi, 4 Ae. longissima, 5 Ae. mutica, 223 Ae. ovata, 83 Ae. peregrina, 25 Ae. searsii, 1 Ae. sharonensis, 50 Ae. speltoides, 40 Ae. tauschii (syn. squarrosa), 75 Ae. triaristata $4 \times$ (syn. neglecta for tetraploids, syn. recta for hexaploids), 249 Ae. triuncialis, 25 Ae. umbellulata, 4 Ae. uniaristata, 22 Ae. vavilovii, 27 Ae. ventricosa. The most BYDV-resistant accessions were evaluated during the 1992-1993 growing season in an elite Aegilops nursery at Sainte-Foy, Quebec, Canada.

\section{Artificial Inoculation}

In field tests at ICARDA, two 1-m rows with 10 plants/meter were grown for each Aegilops accession. At the 4-6 leaf stage, 10-15 viruliferous Rhopalosiphum padi aphids were placed on each plant and after $48 \mathrm{~h}$ these aphids were killed with the insecticide Pirimor. At Sainte-Foy, the accessions 


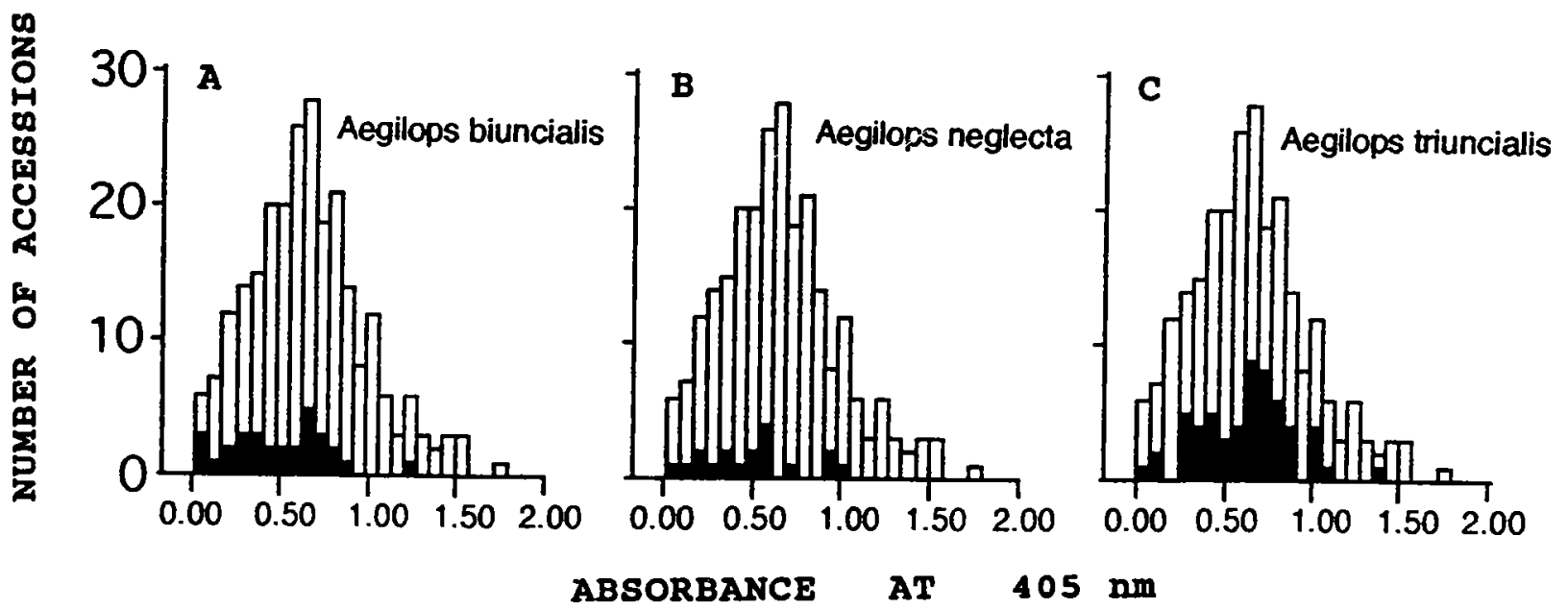

Fig. 1. Distribution of the ELISA values for the Aegilops accessions tested in 1992 (empty bars) as compared to the distribution of the values obtained for the accessions of Ae. biuncialis (A), Ae. neglecta (B) and Ae.triuncialis (C) (solid bars). The average healthy reading of all the Aegilops species tested was 0.16.

were grown in pots and placed in growth chambers operating at $16 \mathrm{~h}$ light and $8 \mathrm{~h}$ of darkness. Temperature of incubation was $22^{\circ} \mathrm{C}$ during the light period and $18^{\circ} \mathrm{C}$ during the dark period. The plants were inoculated at the 4-6 leaf stage with a Quebec isolate of PAV-BYDV using a method similar to that described for the ICARDA tests.

\section{Virus Detection}

At ICARDA, evaluation of Aegilops plants for BYDV was carried out using a variation of the double antibody sandwich ELISA (DAS-ELISA) procedure of Clark and Adams (1977); the leaves were extracted ( $1 \mathrm{~g}$ leaf $/ 1 \mathrm{~mL}$ buffer) in $0.2 \mathrm{M}$ phosphate buffer, $\mathrm{pH}$ 6. ELISA plates (Dynatech) were coated with $1 \mu \mathrm{g} \mathrm{mL}^{-1}$ immunoglobulins (IgG) and the alkaline phosphatase-conjugated IgG was used at a dilution of 1:1000. IgG, used for both coating and conjugate, was purified by the caprylic acid method (Steinbuch and Audran 1969) from a BYDV-PAV antiserum produced earlier in the virology laboratory at ICARDA. Test reactions were quantified spectrophotometrically by measuring absorbance values at $405 \mathrm{~nm}$.

Plants evaluated at Sainte-Foy were tested by tissue-blot immunoassay (TBIA). The TBIA procedure used the chromogenic substrate, nitro blue tetrazolium (NBT)/5-bromochloro-3-indolyl phosphate (BCIP) (Lin et al. 1990; Hsu and Lawson 1991; Makkouk et al. 1993). Test reaction was evaluated by counting the number of phloem bundles stained with a distinctive blue-purple colour. At the time of the ICARDA trial, the TBIA method for detection of BYDV was not available, hence DAS-ELISA was the logical choice.

\section{RESULTS}

Virus content in the Aegilops accessions at ICARDA varied from almost zero to a relatively high level (ELISA value of 1.875 ). The data were interpreted using a positive-negative threshold, calculated as the healthy mean plus $3 \mathrm{SD}$. The thresholds varied slightly among the species tested and among the growing seasons (0.110-0.225). The 1991-1992 data were easy to interpret, because the difference between the resistant and susceptible entries was large and the distribution was close to normal (Fig. 1, empty bars). Most accessions of Ae. biuncialis and Ae. neglecta occupied the left side of the distribution curve, suggesting that virus multiplication was lower than in the other species tested. In 1992, some accessions of these two species had very little virus; a few Ae. triuncialis accessions were also very resistant (Fig. 1, A, B,C).

A group of Aegilops accessions that demonstrated a low level of virus multiplication at ICARDA was tested against a Quebec BYDV-PAV isolate. The TBIA method revealed a variability in the extent of virus invasion of the phloem vessels as measured by the number of stained bundles (Fig. 2). In comparison to that of the BYDV-tolerant wheat cultivar Maringa, virus invasion in all of these accessions was reduced. A number of Aegilops accessions showed a very low level of virus $5,7,11,21$ and $60 \mathrm{~d}$ after virus inoculation (Table 1).

\section{DISCUSSION}

There was a wide difference in BYDV titer among the Aegilops accessions tested reflecting differences in their genetic response to BYDV. None was immune to BYDV infection as shown with some Thinopyrum accessions (Comeau and Plourde 1987). However, a high level of BYDV resistance was found in a few accesssions of $A e$. caudata, Ae. biuncialis, Ae. neglecta and Ae. triuncialis.

As a diagnostic tool for detecting BYDV, TBIA has been proven to be a very sensitive and simple procedure (Makkouk et al. 1994). This technique detects low levels of this virus in the plant tissue, avoiding false positives because the shape and localization of the stained dots has a high diagnostic value; therefore it does not require a positive threshold value.

Trials in Quebec in 1981 on 100 accessions of Aegilops, mostly Ae. tauschii (= squarrosa) and on 25 accessions of 


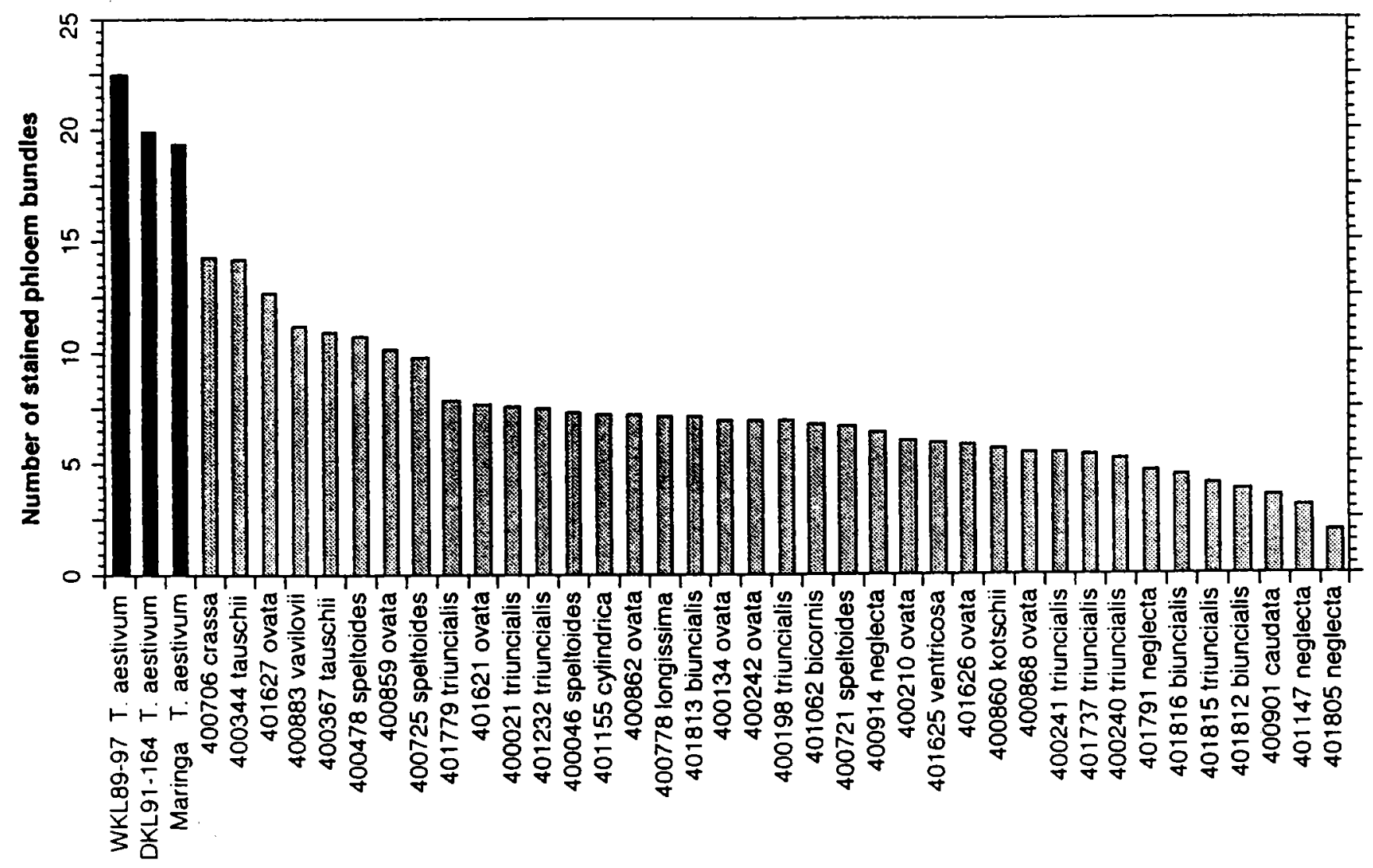

Fig. 2. Average number of stained phloem bundles per stem section of selected accessions from 14 Aegilops species when tested by the tissue-blot immunoassay. Each value represents the average of four readings at 5, 7, 11 and $21 \mathrm{~d}$ after BYDV-PAV inoculation, with four replications for each date.

\begin{tabular}{|c|c|c|c|c|c|c|c|c|}
\hline \multirow{2}{*}{ Germplasm } & \multirow{2}{*}{$\begin{array}{c}\text { ICARDA } \\
\text { accession } \\
\text { number }\end{array}$} & \multirow{2}{*}{$\begin{array}{l}\text { Geographical } \\
\text { origin }\end{array}$} & \multicolumn{6}{|c|}{ Number of stained phloem bundles $\mathbf{z}$} \\
\hline & & & 5 & 7 & Days & cula & 60 & Mean \\
\hline \multirow{2}{*}{\multicolumn{9}{|c|}{ Aegilops }} \\
\hline $\begin{array}{l}\text { Aegliops } \\
\text { caudata }\end{array}$ & & Suria & 2 & 6 & 3 & 3 & 7 & 4.2 \\
\hline \multirow[t]{3}{*}{ neglecta } & $\begin{array}{l}400901 \\
401147\end{array}$ & Turkey & 1 & 2 & 9 & 1 & 11 & $\begin{array}{l}4.2 \\
4.8\end{array}$ \\
\hline & 401791 & Bulgaria & 5 & 2 & 6 & 7 & - & 5.0 \\
\hline & 401805 & Bulgaria & 2 & 0 & 1 & 4 & 7 & 2.8 \\
\hline \multirow{2}{*}{ biuncialis } & 401812 & Bulgaria & 6 & 2 & 4 & 4 & 7 & 4.6 \\
\hline & 401816 & Bulgaria & 7 & 4 & 4 & 3 & 6 & 4.8 \\
\hline triuncialis & 401815 & Bulgaria & 6 & 4 & 2 & 5 & 3 & 4.0 \\
\hline \multicolumn{9}{|l|}{ Triticum } \\
\hline aestivum "Maringa" & & Brazil & 32 & 17 & 10 & 18 & 30 & 21.4 \\
\hline
\end{tabular}

${ }^{\mathbf{z}}$ Each value represents the average number of stained phloem bundles of four stem (including leaf sheath) sections. The stain deposit occurs specifically around virus particles adsorbed on the membrane, so the absence of stained bundles means resistance.

Triticum monococcum and T. urartu showed that diploid A and D genome species were highly susceptible to BYDV. The trials at ICARDA (1991 and 1992) revealed that accessions Ae. neglecta 401147 and Ae. triuncialis 400240 were moderately resistant. These two lines were confirmed as moderately resistant in Sainte-Foy trials (Fig. 2), and have been used in crosses with wheat.
The species identified as resistant possess genomes UM (Ae. biuncialis and Ae. neglecta), CU (Ae. triuncialis) and C (Ae. caudata). Chromosome counts are needed to distinguish tetraploid from hexaploid lines within accessions labeled as $A e$. triaristata. According to some taxonomists, these are different species, Ae. neglecta $(4 \times)$ and Ae. recta $(6 \times)$, but there is no consensus. The crossing and backcrossing should 
be relatively easy with $A e$. triuncialis and Ae. caudata. We are aware of slight difficulties in creating the $\mathrm{F}_{2}$ with $A e$. neglecta. This cross was more difficult than the $T$. aestivum/ Ae. tauschii cross. The rate of $\mathrm{F}_{1}$ plant regeneration was about $1 \%$ in our previous studies (Comeau et al. 1992). The backcrossing difficulty was reduced at Sainte-Foy by the use of bread wheat cultivars AC Mimi and AC Pollet as initial mother plants. Chromosome pairing between A, B, D and the $\mathrm{C}, \mathrm{U}, \mathrm{M}$ genomes may be very low (Riley and Law 1965). Introgression of genes into wheat from resistant accessions of the four species reported in this study should therefore be greatly improved by the use of the high-pairing promoter phlb (Ceoloni et al. 1988), or by other methods aiming at the same goal.

The present study indicates that some Aegilops accessions may provide useful sources of BYDV resistance.

\section{ACKNOWLEDGMENT}

The BYDV isolate used in this study at Sainte Foy, Quebec, was isolated earlier by C. Cloutier. Laval University, Sainte Foy, Quebec, and identified as a PAV serotype by W.F. Rochow, Cornell University. New York.

Brettell, R. I. S., Banks, P. M., Cauderon, Y., Chen, X., Cheng, Z. M., Larkin, P. J. and Waterhouse, P. M. 1988. A single wheatgrass chromosome reduces the concentration of barley yellow dwarf virus in wheat. Ann. Appl. Biol. 13: 599-603.

Cauderon, Y. 1979. Use of Agropyron species for wheat improvement. Pages 129-139 In Proc. Conf. Broadening Genetic Base of Crops, Wageningen. The Netherlands.

Ceoloni, C., Del Signore, G., Pasquini, M. and Testa, A. 1988. Transfer of mildew resistance from Triticum longissimum into wheat by $p h I$ induced homoeologous recombination. Pages 221-226 in Proc. 7th Int. wheat Genet. Symp.. Cambridge, U.K.

Clark, M. F. and Adams, A. N. 1977. Characteristics of the microplate method enzyme-linked immunosorbent assay for the detection of plant viruses. J. Gen. Virol. 34: 475-483.
Comeau, A., Nadeau, P., Plourde, A., Simard, R., Maes, O., Kelly, S., Harper, L., Lettre, B., Landry, B. and St-Pierre, C. A. 1992. Media for the in ovulo culture of proembryos of wheat and wheat-derived interspecific hybrids or haploids. Plant Sci. 81: 117-125.

Comeau, A. and Plourde, A. 1987. Cell tissue culture and intergeneric hybridization for barley yellow dwarf virus resistance in wheat. Can. J. Plant Pathol. 9: 188-192.

Comeau, A. and St-Pierre, C. A. 1992. Interspecific hybridization: a new reservoir of resistance to barley yellow dwarf virus. Pages 197-206 in A. Comeau and K. M. Makkouk, eds. Barley yellow dwarf in West Asia and North Africa. Aleppo, Syria.

Comeau, A., St-Pierre, C. A. and Collin, J. 1993. Interspecific hybrids of wheat as sources of barley yellow dwarf virus resistance. Pages 83-94 in A. B. Damania, ed. Biodiversity and wheat improvement. John Wiley, Chichester, U.K. 434 pp.

Hsu, H. T. and Lawson. R. H. 1991. Direct tissue blotting for detection of tomato spotted wilt virus in Impatiens. Plant Dis. 75: 292-295.

Lin, N. S., Hsu, Y. H. and Hsu, H. T. 1990. Immunological detection of plant viruses and a mycoplasma like organism by direct tissue blotting on nitrocellulose membranes. Phytopathology 80: 824-828.

Makkouk, K. M., Hsu, H. T. and Kumari, S. G. 1993. Detection of three plant viruses by dot-blot and tissue-blot immunoassays using chemiluminescent and chromogenic substrates. J. Phytopathol. 139: 97-102.

Makkouk, K. M., Comeau, A. and St-Pierre, C. A. 1994. Screening for barley yellow dwarf luteovirus resistance in barley on the basis of virus movement. J. Phytopathol. (In press).

Riley, R. and Law, C. N. 1965. Genetic variation in chromosome pairing. Adv. Gen. 13: 57-114.

Sharma, H. C., Gill, B. S. and Uyemoto, J. K. 1984. High levels of resistance in Agropyron species to barley yellow dwarf and wheat streak mosaic viruses. Phytopathol. Z. 110: 143-147.

Steinbuch, M. R. and Audran, R. 1969. The isolation of IgG from mammalian sera with the aid of caprylic acid. Arch. Biochem. Biophys. 134: 279-284. 